\title{
The Effects of Juridification on States Exiting International Institutions
}

\begin{abstract}
This article complements the doctrine of termination of membership by arguing that at times international organizations (IOs) can still exert considerable normative effects on states that withdraw or express the intent to withdraw from them. We capture this continuing influence, which can collide with the exiting state's intended goal of regaining control over specific issues, with a theoretical framework based on juridification as a socio-legal concept of systems theory in the international legal context. The aim is to explain the endogenous process of legal growth within the IO via bureaucratization and expert rule, which eventually affects the norms of the wider legal regime where the IO operates. With three case studies of IO exits, we illustrate the continuation of normative structures promoted directly or indirectly by the IO, according to two legal techniques of juridification: third-party interpretation on the one hand, and the extended reach of norms and processes through the work of non-state actors on the other. Overall, widening the theoretical perspective on state exits under systems theory can lead to more complete judgements on the tensions between domestic and supranational systems in the expansion of global normative regimes.
\end{abstract}

Keywords: Juridification - membership of international organizations - unilateral withdrawal - termination of membership - systems theory - human rights international investment law - climate change 
Nicolas Kang-Riou

Lecturer in Law, University of Salford

n.kang-riou@salford.ac.uk

David Rossati

Lecturer in Law, University of Salford

d.rossati@salford.ac.uk

Acknowledgments:

We thank the participants in the 2017 workshop of the ESIL Interest Group on

International Organizations for their comments on an early version of this paper. We are also grateful to Paolo Sandro, as well as the anonymous reviewers for their thoughtful criticisms and helpful suggestions. Of course, all errors are our own.

\section{Introduction}

In 2001, Klabbers argued that perceptions about the role of international organizations (IOs) ${ }^{1}$ in the world order were changing. ${ }^{2}$ Being seen as an 'embodiment of the dream of legislative reason' ${ }^{3}$ IOs have multiplied in number, with the membership of global organizations, such as the UN and the World Trade Organization, dramatically expanding and seemingly following a pattern of constant progress.

\footnotetext{
${ }^{1}$ In this study, we understand IOs widely by including international institutions created under multilateral treaties, even if they lack international legal personality. See Henry G Schermers and Niels M Blokker, International Institutional Law (Martinus Nijhoff, 5th Revised, 2011) 45. We also attribute the same meaning to the terms 'IOs' and 'international institutions'; as well as to 'international institutional law' and 'law of international organizations'.

2 Ian Klabbers, 'The Changing Image of International Organizations' in Jean-Marc Coicaud and Heiskanen (eds), The Legitimacy of International Organizations (United Nations University Press, 2001) 221.

${ }^{3}$ Ibid 222. See also, José E Alvarez, 'International Organizations: Then and Now' (2006) 100(2) American Journal of International Law 324.
} 
Nevertheless, what would have appeared as a steady path has also led to unexpected unilateral withdrawals of states from IOs (exits), ${ }^{4}$ thus signalling that, perhaps, IOs are no longer exclusively 'considered to be a good thing'. 5

Exits from IOs can take place for all sorts of reasons and often states have used them for the strategic purpose of challenging particular situations within organizations, by later re-joining the ranks once an acceptable solution was reached. ${ }^{6}$ Yet, in the current period of 'contested multilateralism', 7 the recent cases of 'Brexit' and the withdrawals of some states from the International Criminal Court ${ }^{8}$ have further highlighted the uneasy relationships between domestic orders and those developed multilaterally through the works of international institutions.

One of the causes of such tensions is the perception that the IO has 'deviated from its original principles and purposes ${ }^{9}$ and that the adoption of key domestic policies, often backed by popular support, has been thwarted by contrasting norms of the IO, which a single member state cannot justifiably oppose from within the organization. From this perspective, we do not find it sufficient to solely rely on the doctrine of termination of membership under international institutional law, given that this is

\footnotetext{
${ }^{4}$ For an overview of notable cases see Schermers and Blokker, above n 1,98.

${ }^{5}$ Klabbers, 'The Changing Image of International Organizations', above n 2, 222.

${ }^{6}$ See Konstantinos D Magliveras, 'Membership in International Organizations' in Jan Klabbers and Aasa Wallendahl (eds), Research Handbook on the Law of International Organizations (Edward Elgar Publishing, 2011) 84, 98-101. Another technique is the temporary suspension of participation in the IO by the state: see the case of Indonesia's suspension of activities in the UN below.

${ }^{7}$ Julia C Morse and Robert O Keohane, 'Contested Multilateralism' (2014) 9(4) The Review of International Organizations 385, 389-390. The concept defines current situations in world politics where states, coalitions and non-state actors engage in the creation of competitive multilateral institutions to challenge existing ones. Exits and their threat play the role of giving voice to the recalcitrant state or coalition.

${ }^{8}$ As of April 2018, South Africa and Gambia have taken back their notification to withdraw, while Burundi's exit has taken effect in October 2017. In March 2018, the Philippines have filed a notification to withdraw from the Rome Statute. See Rome Statute of the International Criminal Court, opened for signature 17 July 19982187 UNTS 3 (entered in force 1 July 2002) 2187 UNTS 3, Chapter XVIII. Penal Matters, 14.

${ }^{9}$ Magliveras, above n 6, 100.
} 
limited to discipline the relations only between the IO and the exiting member (section 1). Instead, we aim to explore those normative effects of the regime internal to the IO which can nonetheless outreach to the exited state, even after the formal termination of membership. In other words, in this article, we posit a theoretical understanding of cases where a state cannot fully escape the normative reach of an IO simply by formally exiting it. ${ }^{10}$ Accordingly, we first offer an outline of the tensions and limitations in the functional theory of IOs in encompassing events outside the direct relationship between state members and the IO (section 1). Following this discussion, we revamp the sociolegal concept of juridification developed under systems theory, ${ }^{11}$ but intuited by international legal scholarship (section 2), which explains the constant growth of rules in an IO, fostered by expert rule and bureaucratization. In particular, in section 3 we reconstruct IOs as 'organization systems', participating in wider 'function systems'. Their interactions enable an analysis of initial structures and patterns where exiting the organization system does not necessarily entail leaving its norms or processes, because of their continued presence in the wider function system.

By applying this grid of analysis to three exit events or threats of exits involving, respectively, the first Optional Protocol of the International Covenant on Civil and Political Rights, the International Centre for the Settlement of Investment Disputes, and the Paris Agreement on climate change (section 4), we reach two conclusions. Juridification not only stands at the roots of some exit events, but through informal

\footnotetext{
${ }^{10}$ Ramses A Wessel, 'You Can Check out Any Time You like, but Can You Really Leave?' (2016) 13(2) International Organizations Law Review 197.

${ }^{11}$ Jürgen Habermas, The Theory of Communicative Action, Volume 2: Lifeworld and System: A Critique of Functionalist Reason (Beacon Press, 1985).
} 
networks of communications by various legal actors -state or non-state- it moulds and perpetuates normative structures (section 5).

\section{Exits and the law of international organizations}

When dealing with unilateral state withdrawals from IOs (hereinafter 'exits'), the prevalent focus of international institutional law scholars is on termination of membership. ${ }^{12}$ This has led to developing an exit doctrine in the law of international organizations, which systematizes the many interactions between state members and the IO under the law by relying on functionalism as its foundational theory. Its descriptive prong is that states act as principals to an autonomous agent entity (the IO) entrusted with performing a range of functions stemming from the constitutive agreement. ${ }^{13}$ The normative prong of functionalism, in turn, defines states both as members of the IO and parties to a multilateral treaty: consequentially, most authors rely on a dualist understanding of the relationship between the IO and its members under international law. ${ }^{14}$ When a state exits an IO, this can be regarded as a pure matter of treaty

\footnotetext{
${ }^{12}$ Stephen Mathias and Stadler Trengove, 'Membership and Representation' in Jakob K Cogan, Ian Hurd and Ian Johnstone (eds), The Oxford Handbook of International Organizations (Oxford University Press, 2016) 963; Nagendra Singh, Termination of Membership of International Organisations (Stevens, 1957); CF Amerasinghe, Principles of the Institutional Law of International Organizations (Cambridge University Press, 2005) 117; Schermers and Blokker, above n 1, 98; Philippe Sands and Pierre Klein, Bowett's Law of International Institutions (Sweet \& Maxwell, 2009); Jan Klabbers, An Introduction to International Institutional Law (Cambridge University Press, 2nd ed, 2009) 109-114; Alison Duxbury, The Participation of States in International Organisations: The Role of Human Rights and Democracy (Cambridge University Press, 2011); Magliveras, above n 6.

${ }^{13}$ This is admittedly the prevalent conception of IOs and membership IOs. See Reparation for Injuries Suffered in the Service of the United Nations (Advisory Opinion) [1949] ICJ Rep 174, 180.; see also Jan Klabbers, 'Two Concepts of International Organization' (2005) 2(2) International Organizations Law Review 277. See also Dan Sarooshi, International Organizations and Their Exercise of Sovereign Powers (Oxford University Press, 2005) 109, finding that agency cannot be presumed with regards to all powers exercised by the IO.

${ }^{14}$ See Georges Scelle's doctrine of dédoublement fonctionnel, and the postulate of autonomous will as a condition for existence of an IO: Niels Blokker, 'International Organizations and Their Members' (2004) 1 International Organizations Law Review 139; Nigel White, The Law of International Organisations
} 
withdrawal by a state party, but also signifies the end of the membership status within the internal regime of the IO. Functionalism, which does not look beyond the connections between state members and the IO, has led to two main outcomes in the literature.

First, it has spread unease. Indeed exits feature in many writings as drastic acts of rupture, having the final effect of undermining the constituted (liberal) order of the IO. ${ }^{15}$ This take is particularly evident in those works which see in the burgeoning of IOs after the Second World War a sign of increased international co-operation (if not even constitutionalization) towards some positive values and aspirations. ${ }^{16}$ Second, it has generated a detailed doctrine with classical works offering a taxonomy of exits and their ensuing legal discipline through inductive explorations of constitutive instruments and notable cases -the main types being unilateral withdrawals of states, expulsions of members by the IO, and dissolution (of the state member or the IO). ${ }^{17}$

\footnotetext{
(Manchester University Press, $3^{\text {rd }}$ ed, 2016); Jean d'Aspremont, 'The Law of International Organizations and the Art of Reconciliation' (2014) 11(2) International Organizations Law Review 428.

${ }^{15}$ Schermers and Blokker, above n 1. Sarooshi, above n 13. Expectedly, this attitude also emerged during the early discussions on the right to withdraw from the European Union (EU). During the negotiations for the Treaty Establishing a Constitution for Europe, Friel has compared the issue of withdrawal from EU to constitutional experiences in federal states, criticising how a draft withdrawal clause would threaten the stability of the EU and the withdrawing state. See Raymond J Friel, 'Providing a Constitutional Framework for Withdrawal from the EU: Article 59 of the Draft European Constitution' (2004) 53 International and Comparative Law Quarterly 407.

${ }^{16}$ Bardo Fassbender, 'The United Nations Charter As Constitution of the International Community' (1998) 36 Columbia Journal of Transnational Law 529. See more extensively Anne Peters, 'Membership in the Global Constitutional Community' in Jan Klabbers, Anne Peters and Geir Ulfstein (eds), The Constitutionalization of International Law (Oxford University Press, 2009) 153, 201-219.

${ }^{17}$ See Schermers and Blokker, above $\mathrm{n}$ 1. Klabbers also mentions the suspension of membership rights in alternative to the expulsion of recalcitrant states, and the termination of membership in cases where amendments to the constitutive agreement are not accepted by a member: Klabbers, above n 12, 109-113. Similarly see Amerasinghe, above n 12, 117. Comprehensive works on the theme are Singh, above n 12. Duxbury, above n 12. Konstantinos D Magliveras, Exclusion from Participation in International Organisations: The Theory and Practice behind Member States' Expulsion and Suspension of Membership (Oxford University Press, 1998).
} 
Yet this analytical effort is also limited by the very tensions of dualism in the law of international organizations, ${ }^{18}$ which pose challenges in framing a coherent legal doctrine of exits. One can, for instance, take the vexed debate on unilateral withdrawals in the absence of an express clause in the constituent treaty, ${ }^{19}$ considering the 'textbook case' of Indonesia's withdrawal from the UN, to show how dualism can blur doctrinal clarity. After a notification to withdraw in 1965, a cessation of its participation in UN organs, and reshuffles in the composition of organs to substitute the empty Indonesian seats, Indonesia could nonetheless re-take its seat at the UN General Assembly in the following year, with the UN Secretary General deeming the events as evidence of a temporary cessation of co-operation rather than of membership. ${ }^{20}$ On this event, commentators of that period reacted with relief over the failed attempt of Indonesia to destabilize the $\mathrm{UN},{ }^{21}$ or maintained ambiguity in reconstructing this exceptional case as a formal withdrawal or a simple cessation of participation. ${ }^{22}$

\footnotetext{
18 This difficulty in conciliating the two poles has recently re-emerged in Brexit debates concerning the possibility of unilateral withdrawal of the notification under Article 50(2) of the Treaty on the European Union and its constitutive effects over the exit procedure. For arguments based on the applicability of the Vienna Convention on the Law of Treaties, see Aurel Sari, 'Reversing a Withdrawal Notification under Article 50 TEU: Can a Member State Change Its Mind?’ (2017)

<https://papers.ssrn.com/abstract=2872152>. ; for a EU/member state centered approach Paul Craig, 'The Process: Brexit and the Anatomy of Article 50' in Federico Fabbrini (ed), The Law \& Politics of Brexit (Oxford University Press, 2017) 49, 65.

${ }^{19}$ The viability of unilateral withdrawals without an exit clause in the treaty is still contested. Nigel White is of the view that it should not be allowed in any circumstance, but either induced from the intention of the parties or implied from the nature of the treaty. In the absence of any express or implied consent, states can withdraw only according to the rebus sic stantibus doctrine. See White, above n 14. 116-117. Contra see Schermers and Blokker, above n 1., 108 essentially claiming that the permissibility of unilateral withdrawals eventually depends on states practice and the arguments that the withdrawing state can take. Generally, see N Feinberg, 'Unilateral Withdrawal from an International Organization' (1963) 39 British Year Book of International Law 189.

${ }^{20}$ Egon Schwelb, 'Withdrawal from the United Nations: The Indonesian Intermezzo' (1967) 61(3) The American Journal of International Law 661.

${ }^{21}$ Yehuda Z Blum, 'Indonesia's Return to the United Nations' (1967) 16(2) International \&amp; Comparative Law Quarterly 522.

${ }^{22}$ See Oscar Schachter's interpretation as reported in Ibid 523.
} 
This example confirms how functionalism conflates the principal/agent relationship between member states and the IO to a quasi-closed regime, somehow interacting with or being part of general international law. ${ }^{23}$ Thus functionalism is unable to recognize the normative effects of the IO's regime outside its own boundaries after an exit event, including the effects over the ex-member state.

While states might indeed withdraw from an IO for all sorts of reasons, ${ }^{24}$ more recent studies highlight how IOs and the growth of their normative frameworks can trigger exits due to tensions with domestic policies. For instance, following this perspective, Guzman explores state exits as a political strategy in reaction to the unexpected expansion of an IO's powers. ${ }^{25}$ In an editorial in the aftermath of the Brexit referendum, Wessel questions whether parties can really disentangle the Gordian knot of legal relationships between the EU, its members and third parties. ${ }^{26}$ Despite the intuitions, these recent studies and reflections lack a theoretical framework able to complement the functionalist perspective. Indeed, what the latter cannot comprehend are those instances where the law of an institutionalized regime (whether stemming from international legal sources or the internal law of the IO itself) ${ }^{27}$ can still exert normative effects on the exstate member, once an exit has taken place. If 'functionalism has remained a theory about relations between the organization and its member states [where] other dimensions simply do not and possibly cannot, enter the picture, ${ }^{28}$ then we find it

\footnotetext{
${ }^{23}$ Jan Klabbers, 'The Transformation of International Organizations Law' (2015) 26(1) European Journal of International Law 9; Lorenzo Gasbarri, 'The Dual Legality of the Rules of International Organizations' (2017) 14(1) International Organizations Law Review 87.

${ }^{24}$ Magliveras, above n 6, 98-99.

${ }^{25}$ Andrew Guzman, 'International Organizations and the Frankenstein Problem' (2013) 24(4) European Journal Of International Law 999, 1007-1009.

${ }^{26}$ Wessel, above n 10.

${ }^{27}$ Gasbarri, above n 23.

${ }^{28}$ Jan Klabbers, 'Transforming Institutions: Autonomous International Organisations in Institutional Theory’ (2017) 6(2) Cambridge International Law Journal 105, 119.
} 
worthy to explore what is outside of the functionalist legal doctrine of exits. With this aim, the next section will assess how juridification -a phenomenon of constant expansion of the law in social systems, including IOs- features in the international legal debate and can serve as a useful conceptual took to look beyond functionalism.

\section{Juridification in international legal scholarship}

Concepts akin to juridification have surfaced in international legal discourse in different contexts, meanings and analytical uses. Yet, we can pinpoint two approaches outside systems theory for their relevance and analytical development in the literature. The first concerns the law of international organizations and centres on the use of 'constitutional growth' as a metaphor in the development of major IOs. ${ }^{29}$ As Sinclair finds, since the end of the Second World War, international lawyers and civil servants have adopted a dynamic conception of IOs in terms of their function and law-making powers, in order to accommodate the need to adapt the IO to new events and political shifts. The constitutional growth of IOs has worked as an argumentative tool to advance the idea of change and expansion of IOs' powers and functions via formal and informal means. This is a process internal to IOs, which reflects a functionalist understanding of the relationship between member states and the autonomous entity they create. Whilst on the formal level expansion is facilitated through the works of specific doctrines in international institutional law, ${ }^{30}$ the more informal processes of constitutional growth

\footnotetext{
${ }^{29}$ Guy Fiti Sinclair, To Reform the World: International Organizations and the Making of Modern States (Oxford University Press, 2017) 18. Others have referred to it as 'constitutive juridification': see Lars Chr Blichner and Anders Molander, 'Mapping Juridification' (2008) 14(1) European Law Journal 36, 39.

${ }^{30}$ For instance, the doctrine of implied powers, the principle of attribution and speciality, and the doctrine of competence of organs. These have been mostly formulated through the advisory opinions of the International Court of Justice and the work of the International Law Commission. See Guy Fiti Sinclair,
} 
within IOs are also relevant and take the form of rhetoric by leading figures in the IO, the re-imagining of established IOs activities, or the creation of new ones. ${ }^{31}$ All these elements are related to empowerment of expert rule and bureaucratization through the language of law. ${ }^{32}$ Moreover, constitutional growth can lead to situations where IOs considerably depart from the original vision that member states encapsulated in the constitutive agreement, yet without evidently entering the ultra vires zone. Guzman labels this phenomenon as the 'Frankenstein problem' in international institutional law and pays attention to design techniques in the constitutive agreement for more effective management of the IO's expansion and retraction of powers. ${ }^{33}$

The second strand of the international legal literature linked to juridification can be traced back to the beginning of the new millennium when several US-based authors have started promoting 'legalization' as a concept for rational behaviour analysis of international law and international relations. ${ }^{34}$ Abbott et al. define legalization as a 'set of characteristics' which institutionalized regimes possess in various degrees. These traits are termed respectively obligation, precision and delegation, and capture the various gradients in which institutionalized regimes are governed by 'hard' or 'soft' law, ${ }^{35}$ the level of determinacy of their rules, and the extent of delegated powers given

\footnotetext{
'State Formation, Liberal Reform and the Growth of International Organizations' (2015) 26(2) European Journal of International Law 445, 449-450.

${ }^{31}$ Sinclair, for instance, highlights the leadership role of the UN Secretary General, Dag Hammarskjöld, in the creation and justification of UN peacekeeping intervention during the Congo crisis. Similarly, Albert Thomas, nominated as Office Director of the International Labor Organization, was behind the development of technical assistance activities in member states. See Sinclair, above n 29. Generally, see José Enrique Alvarez, International Organizations as Law-Makers (Oxford University Press, 2005) 328.

${ }^{32}$ See Blichner and Molander, above n 29, who identify in these processes another form of juridification.

${ }^{33}$ Guzman, above n 25.

${ }^{34}$ A strand of the literature criticized for its limitedness to a liberal international relations analysis of international law. See Martha Finnemore and Stephen J Toope, "Alternatives to "Legalization": Richer Views of Law and Politics' (2001) 55(3) International Organization 743.

35 This is a view espousing 'relative normativity' in international law. In the context of positivist approaches, see Ulrich Fastenrath, 'Relative Normativity in International Law' (1993) 4 European
} 
to third parties to apply and enforce these rules. ${ }^{36}$ With these three coordinates, the authors do not identify any ideal superiority to specific forms of legalization, but rather use the concept to categorize international regimes and determine the political strategies that states are likely to adopt as rational actors in the multilateral domain. While much attention is given to international regime designs to explain their cost/benefit consequences, 'regime exit' strategies are not considered, ${ }^{37}$ although they would likely fit within the realm of strategic responses to legalization. This latter aspect has been further developed by Helfer, who concentrates on exits from human rights regimes prompted by 'overlegalization'. In his account, the prefix 'over' determines a situation with 'more extensive changes to national laws and practices than was the case when the state first ratified the treaty, generating domestic opposition to compliance or pressure to revise or exit from the treaty'. ${ }^{38}$ This study, which looks at the legalization of the Commonwealth Caribbean human rights regime and responses by some of its states, ${ }^{39}$ is the most detailed conceptualization of juridification and its linkage to treaty exits in the literature. However, it lacks a clear reference to the role of IOs and international institutional law in the process and rather concentrates on the backlash that increased legalization exerts on the effectiveness of the said regime and international relations theories. ${ }^{40}$ Helfer has also offered an extensive empirical study of multilateral treaty exits, discovering how states quit multilateral treaties with a fair degree of regularity

\footnotetext{
Journal of International Law 305. Contra Prosper Weil, 'Towards Relative Normativity in International Law?' (1983) 77(3) The American Journal of International Law 413.

${ }^{36}$ Kenneth W. Abbott et al, 'The Concept of Legalization' (2000) 54(3) International Organization 401.

${ }^{37}$ Kenneth W. Abbott and Duncan Snidal, 'Hard and Soft Law in International Governance' (2000) 54(3) International Organization 421.

${ }^{38}$ Laurence Helfer, 'Overlegalizing Human Rights: International Relations Theory and the Commonwealth Caribbean Backlash Against Human Rights Regimes' (2002) 102 Columbia Law Review $1832,1854$.

${ }^{39}$ The same case is also analyzed below according a revised conceptualization of juridification. See below section 4 .

${ }^{40}$ Helfer, above n 38 .
} 
and considering the effect of withdrawal clauses on 'exit costs' in case of unwanted outcomes from the agreement. ${ }^{41}$ Yet the same analysis turns to the politics of treaty exits assuming rational behaviour from states and does not look at the role of IOs and their internal law and regulatory processes in the context of legalization.

Overall, although several international law scholars have theorized the idea of incremental stages of legal growth of IOs, they have not paid systematic attention to the specific normative effects of such development, which can take place outside the institutional regimes. Also, they do not offer a framework able to comprehend how juridification can be at the same time one of the causes of an exit, but also the means for extending the juridified regime internal to the IO on the exiting state.

\section{Systems theory, juridification and exits}

This section sets up a descriptive and normative framework of exits from the sociology of law and systems theory based on juridification. ${ }^{42}$ By viewing IOs as 'autopoietic social systems' participating in a wider international legal regime ('function system') ${ }^{43}$ we provide explanations as to why juridification occurs and why states may object to this juridification by exiting IOs. Moreover, we dissect how the normative effects of juridification spread through the wider function system and continue affecting the exiting state.

\footnotetext{
${ }^{41}$ Laurence Helfer, 'Exiting Treaties' (2005) 91 Virginia Law Review 1579, 1608.

${ }^{42}$ For a positioning of systems theory within contemporary approaches to international law see: Ingo Venzke, 'Contemporary Theories and International Lawmaking' in Research Handbook on the Theory and Practice of International Lawmaking (Edward Elgar Publishing, 2016) 77.

${ }^{43}$ Function systems deal with specific subject matters contrasted with organization systems. An IO is an organization system but also participates to function systems (for example, international human rights law etc).
} 
To better understand the process, it is necessary to go back to the theory which first underpinned the concept of juridification in domestic legal systems. The idea of juridification ('Verrechtlichung') uses concepts from systems theory and has been popularized at the beginning of the $20^{\text {th }}$ century by the German doctrine in the context of the massive regulatory expansion of the welfare state model.${ }^{44}$ In particular, Habermas ${ }^{45}$ defined juridification as 'the tendency towards an increase in formal (or positive, written) law that can be observed in modern society' ${ }^{46}$ composed as 'the expansion of law, that is the legal regulation of new, hitherto informally regulated social matters, [and] the increasing density of law' ${ }^{47}$ It is also possible to distinguish a recent move from juridification by 'direct regulation of behaviours to a more indirect regulation of procedures'. ${ }^{48}$

Lately, the approach has also been applied to the international sphere, ${ }^{49}$ with the process of juridification in IOs manifesting in the wider context of global constitutionalism. For Habermas (and Teubner), the multiplication of specialized regimes $^{50}$ is a direct consequence of the juridification of international law through constitutionalization. ${ }^{51}$ However, specialized regimes are not necessarily coordinated or

\footnotetext{
${ }^{44}$ Gunther Teubner, 'Juridification: Concepts, Aspects, Limits, Solutions' in A Reader on Regulation (Oxford University Press, 1998).

${ }^{45}$ Habermas, above n 11.

46 Ibid 356.

${ }^{47}$ Ibid.

48 Teubner, 'Juridification: Concepts, Aspects, Limits, Solutions', above n 44, 424.

${ }^{49}$ Gunther Teubner and Andreas Fischer-Lescano, 'Regime-Collisions: The Vain Search for Legal Unity in the Fragmentation of Global Law' (2004) 25(4) Michigan Journal of International Law 999; Lena Hilkermeier and Mathias Albert, 'Organizations in/and World Society A Theoretical Prolegomenon' in Mathias Albert and Lena Hilkermeier (eds), Observing International Relations : Niklas Luhmann and World Politics. (Taylor and Francis, 2003) 177; Jürgen Habermas, The Divided West (Polity, 2006).

${ }^{50}$ Friedrich Kratochwil and John Gerard Ruggie, 'International Organization: A State of the Art on an Art of the State' (1986) 40(4) International Organization 753. Teubner and Fischer-Lescano, above n 49.

${ }^{51}$ Habermas, above n 49, 115; Niklas Luhmann, Law as a Social System (Oxford University Press, 2008); Gunther Teubner, Constitutional Fragments: Societal Constitutionalism and Globalization. (Oxford University Press, 2012) 8.
} 
part of a unidirectional movement ${ }^{52}$ and they can even 'collide'. ${ }^{53}$ Whatever their links, regimes rely on law's expansion and differentiation. ${ }^{54}$ For Teubner and FischerLescano, the societal fragmentation induced by globalization 'impacts upon law in a manner such that the political regulation of differentiated societal spheres requires the parcelling out of issue-specific policy-arenas, which, for their part, juridify themselves' ${ }^{55}$ Put simply, it means that the breaking up of globalization in various spheres is done through a juridification process.

Within this general configuration, systems theory constructs organizations as 'autopoietic' (self-reproducing) social systems. 'Organizations consist of decisions and these decisions are recursively linked to each other' ${ }^{56}$ As a consequence, an organization is normatively closed but informationally open against any events coming from the external environment, meaning that legal acts not recognized by the system have no legal value but any act or event occurring in the system can be used to justify a decision. ${ }^{57}$

An IO can be considered as an autopoietic social system as soon as it differentiates itself from the constituting member states and begins deciding on the operation of the constitutive treaty (the 'legal code' of the organization) based upon its own interpretation. The relationship between juridification and autopoiesis is made apparent by Bohman, as the term 'juridification' points to the idea of a 'legal domination [which]

\footnotetext{
52 Nico Krisch, Beyond Constitutionalism: The Pluralist Structure of Postnational Law (Oxford University Press, 2010).

53 Teubner and Fischer-Lescano, above n 49.

${ }^{54}$ Blichner and Molander, above n 29, 42.

55 Teubner and Fischer-Lescano, above n 49, 1009.

${ }^{56}$ Hilkermeier and Albert, above n 50, 186.

${ }^{57}$ Luhmann, above n 51, 60. Tor Hernes and Tore Bakken, 'Implications of Self-Reference: Niklas Luhmann's Autopoiesis and Organization Theory’ (2003) 24(9) Organization Studies 1511.
} 
is not simply tyranny, but rather the imposition of a cooperative scheme upon others who cannot influence or revise its terms. ${ }^{58}$ The juridification of IOs leads to an autopoietic social system, so that 'in the field of law, autopoietic self-reference means that its validity is based solely on legal normativity and that legal validity has definitely freed itself from all extra-legal connections - politics, morality, science'. ${ }^{59}$ Therefore, the IO needs to be sufficiently juridified to be treated as an autopoietic social system.

On that basis, decisions within IOs can only happen according to their internal rules with the organization system being operationally closed or bounded.$^{60}$ At the same time, social systems are informationally open to their environment. ${ }^{61}$ But the way they receive information from the environment happens only according to their own code. Thus, it is possible for IOs to use general international law or any other form of information coming from their environment, but that will only happen through the 'structural coupling ${ }^{62}$ between the systems. For IOs, this means that external information will be received only according to their interpretation of their constitutive treaty (for example, it could be rejected on the basis of lex specialis or integrated on the basis of general international law).

This feature of IOs as social systems explains why they only function according to their legal code, and register contrasting positions taken by member states only, and only if, this code permits it. This does not mean that decisions on the legality of behaviours cannot depart from a literal view of what the constitutive document allows.

\footnotetext{
${ }^{58}$ Cited by Blichner and Molander, above $\mathrm{n} 29$.

59 Teubner, 'Juridification: Concepts, Aspects, Limits, Solutions', above n 44, 406.

${ }^{60}$ Tor Hernes and Tore Bakken, above n 57.

${ }^{61}$ Luhmann, above n 51, 110-111.

62 'Coupling mechanisms are called structural couplings if a system presupposes certain features of its environment on an ongoing basis and relies on them structurally', Ibid 382.
} 
Allowing such a reading only depends on what the actors of the social system accept as being legal. ${ }^{63}$

Under this perspective, the tensions created in the process of 'structural coupling' between law and politics within juridified IOs becomes a major issue for domestic systems. In domestic law, this coupling is produced by the constitution, ${ }^{64}$ while, in democracies, it is formally secured by attributing specific authority to the elected politicians and other representative authorities. However, it is partially lacking within juridified IOs. This means that member states cannot behave in accordance with the IO’s regime by merely asserting an interpretation of their obligations as aligned with their domestic interests. ${ }^{65}$

The distance between domestic politics and decisions of the IO through weak structural coupling is compounded by several processes at play within IOs due to juridification. Bureaucratization is one of the most prominent ones. ${ }^{66}$ According to Weber, a bureaucracy is the 'purest type of exercise of legal authority', ${ }^{67}$ and as such a development of law demands an expansion of administration. The second is the rise of expert rule, ${ }^{68}$ whereby legal experts come to make the key decisions on how to interpret the constitutive treaty and the associated rules.

\footnotetext{
${ }^{63}$ Thus, we are not concerned as to whether decisions made within an organization system are potentially ultra_vires under the constitutive treaty. What matters here is that the decision is made and accepted within the system itself.

${ }^{64}$ Teubner and Fischer-Lescano, above n 49.

${ }^{65}$ Prior to juridification, the state could use interpretative declarations as accepted in general international law.

${ }^{66}$ Ingo Venzke, 'International Bureaucracies from a Political Science Perspective - Agency, Authority and International Institutional Law' in Armin Von Bogdandy, Philipp Dann and Matthias Goldmann (eds), The Exercise of Public Authority by International Institutions (Springer, 2010) 67.

${ }^{67} \mathrm{M}$ Weber and T Parsons, The Theory of Social and Economic Organization (Free Press, 1968) 277.

${ }^{68}$ Martti Koskenniemi, 'The Fate of Public International Law: Between Technique and Politics' (2007)

70(1) The Modern Law Review 1.
} 
The very broad terms used in many international agreements can initially be chosen to allow states to join in, even in light of substantial disagreements. However, once expert rule starts and the interpretation of key terms is left to a third-party, states find it more difficult to express and act according to their different viewpoints without being seen to be in breach of the IO's rules. Furthermore, bureaucratization entrenches the differences between the IO, as a social system, and its environment, as it relies on a growing body of internal rules to decide on its own operations. ${ }^{69}$

As decisions within the juridified IO increasingly stem from some self-defined objectives, rather than genuinely reflecting the collective or individual interests of the member-states, clashes between IO supervisory organs and some states are likely to happen, ${ }^{70}$ with one rational response being to quit this social system. Under this logic, exits effects should be for the decisions of the IO to no longer affect the state.

However, international regulation does not only happen through participation in international organizations, but increasingly also via state participation in specialized parallel regimes ${ }^{71}$ generating interaction via conflicts and linkages. ${ }^{72}$ The behaviour of a state is going to be constrained not only because of the membership of an organization, but also through participation in the wider functional regime where the IO operates. Systems theory extensively explains this process. ${ }^{73}$ It describes how the decisions of the organization are a social system, but at the same time any decision of the organization or 'communication within and of an organization is always also communication within

\footnotetext{
${ }^{69}$ Habermas, above n 11, 306-307.

${ }^{70}$ Martti Koskenniemi, 'Hegemonic Regimes' in Margaret A Young (ed), Regime Interaction in International Law (Cambridge University Press, 2012) 305.

${ }^{71}$ Kratochwil and Ruggie, above n 50. Teubner and Fischer-Lescano, above n 49, 1005.

${ }^{72}$ Some of these issues have also been discussed under the term of 'informal international law making'. See in particular: Joost Pauwelyn, Ramses Wessel and Jan Wouters (eds), Informal International Lawmaking (Oxford University Press, 2012).

${ }^{73}$ Hilkermeier and Albert, above n 49.
} 
a function system' ${ }^{74}$ The IO, then, participates in 'function systems' of the international society, such as those concerned with human rights, international investments or climate change. As a consequence, the IO must be seen as both an organization system (distinguished from their environment by deciding on membership other issues ${ }^{75}$ ) and as a function system of the international society (dedicated to produce communications on a specific subject). As each system is independent and autopoietic, there is no hierarchy between them. This is fully applicable to the international legal order where there is neither hierarchy between organizations, nor between regimes.

Even though such systems lack the formal constitutive instrument of an IO, they grow as function systems in connection to IOs, by developing the core characteristics of an autopoietic legal system, namely self-reference and self-reproduction. ${ }^{76}$ For these reasons, the concept of juridification not only enables us to widen the perspective on the normative relationships between exiting states and IOs, but also the limitations of exits. Under the formalist approach of international institutional law, exit only matters within the organization system, as the state is no longer a member of that organization and party to the constitutive instrument. However, exit might have a limited impact on the function system, depending on the extent and reach of juridification of the IO beyond its boundaries. Systems theory charts the less noticed paths where, despite the conflictual relationship between the juridified IO and the exiting state, the expected legal positioning of the latter outside the IO's influence is nonetheless negated by the

\footnotetext{
74 Ibid 183.

75 Ibid.

76 Teubner and Fischer-Lescano, above n 49. For a discussion of the possibility of these function regimes and a further analysis of the problems of coordination: see also Gunther Teubner, Global Bukowina: Legal Pluralism in the World Society in Global Law without a State (Brookfield, 1997) 13-19; Stefan Oeter, 'International Law and General Systems Theory' German Yearbook of International Law 72, 7576.
} 
normative effects and constraints created by juridification itself. Therefore, the impact of the function regime will happen due to the necessary participation of the exiting state in the globalized world society which has produced these function systems.

In the next section, three exit case studies illustrate how juridification and its consequences have played out in different IOs and legal regimes.

\section{Three cases of juridification and exits}

In this section, three case studies illustrate how juridification generates normative effects beyond the organization system of IOs in case of exits (intended or executed). Not only for each case, the decision to exit has been justified also by reference to an incompatibility with the constitutional order, or democratic (il)legitimacy, but the juridification has also continued to produce constraints on the exiting states, limiting the intended impact of the exit.

\subsection{Exiting the Optional Protocol of the International Covenant on Civil and}

\section{Political Rights}

International human rights law can partly be seen as a function regime as the informal coordination of supervisory bodies produces unified interpretations. This view is centred around the bundle of international human rights organizations and bodies under the UN and at the regional level. The International Court of Justice in the Diallo case exemplifies the use of convergent interpretations of human rights bodies as well as the recognition of the dominance of the Human Rights Committee, the Inter-American Court of Human Rights and the European Court of Human Rights as the core 
institutions of this function system. ${ }^{77}$ The Strasbourg Court has also endorsed this view by using the 'consensus emerging from specialized international instruments' in order to interpret the provisions of the European Convention on Human Rights (ECHR) ${ }^{78}$ The regime actors even extend to include domestic courts. ${ }^{79}$ The function system is thus organised through self-reference of the various connected actors.

Jamaica's and Trinidad and Tobago's withdrawals from the first Optional Protocol of the International Covenant on Civil and Political Rights (OP-ICCPR $)^{80}$ and the American Convention on Human Rights (ACHR) ${ }^{81}$ are good examples of how the participation in the organization system also triggers a participation in the wider function regime. Jamaica and Trinidad and Tobago have used exits as a first reaction to the juridification of human rights imported from international human rights law, rendering it impossible to legally implement the death penalty. In 1997, Jamaica denounced the first OP-ICCPR to bar individual communications to the Human Rights Committee, ${ }^{82}$ and in May 1998, Trinidad and Tobago withdrew from both the first Optional Protocol ${ }^{83}$ and the $\mathrm{ACHR}^{84}$. Each act was momentous and seen as a significant blow to the international human rights system, being the first of a kind. ${ }^{85}$ Still, the

\footnotetext{
77 The ICJ had to interpret in substance article 13 of the International Covenant on Civil and Political Rights. Case concerning Ahmadou Sadio Diallo (Republic of Guinea v. Democratic Republic of the Congo) (Judgment) [2010] ICJ Rep 639, [66]-[68].

${ }^{78}$ Demir and Baykara v. Turkey [GC] [2008] Eur Court HR 1345.

${ }^{79}$ Christopher McCrudden, 'Common Law of Human Rights?: Transnational Judicial Conversations on Constitutional Rights’ (2000) 20(4) Oxford Journal of Legal Studies 499.

${ }^{80}$ Opened for signature 16 December 1966, 999 UNTS 171 (entered into force 23 March 1976).

${ }^{81}$ Opened for signature 22 November 1969, 1144 UNTS 1 (entered into force 18 July 1978).

${ }^{82}$ Natalia Schiffrin, 'Jamaica Withdraws the Right of Individual Petition Under the International Covenant on Civil and Political Rights' (1998) 92(3) The American Journal of International Law 563.

${ }^{83}$ Trinidad and Tobago rejoined the OP-ICCPR with a death-penalty related reservation in August 1998. However as this reservation was later found to be illegal by the Human Rights Committee, it denounced the OP-ICCPR again. This time for good. See Yogesh Tyagi, 'The Denunciation of Human Rights Treaties' (2009) 79(1) British Yearbook of International Law 86, 174-175.

${ }^{84}$ Helfer, above $\mathrm{n} 38$.

${ }^{85}$ Schiffrin, above n 82 . Tyagi, above n 83 .
} 
juridification process went beyond withdrawal. In social systems terminology, the withdrawal has only affected the participation in the organization system, not the function system of human rights law.

In Jamaica and Trinidad and Tobago (as in other Caribbean countries which are part of the British Commonwealth), the UK Judicial Committee of the Privy Council ${ }^{86}$ has remained the highest court after independence. ${ }^{87}$ In that capacity, it provides a judicial review based on the rights guaranteed by the domestic constitution; these rights include the prohibition of torture and inhuman or degrading treatment or punishment.

In Pratt v. Attorney-General for Jamaica, ${ }^{88}$ the Privy Council decided that the Jamaican constitution had to be applied in line with the interpretation provided by international human rights law seen as a function system. It referred to an array of decisions of domestic courts (US and Indian Supreme Courts) and international organs (Committee of Human Rights, Inter-American Commission on Human Rights, and even the European Court of Human Rights and its landmark Soering case $\left.{ }^{89}\right)$. It found that there was a consensus to the view that the death row phenomenon (the considerable time spent prior to execution due to various appeals as well as stressful detention conditions $)^{90}$ could amount to an inhuman and degrading treatment.

The Privy Council stated that any death row which lasted more than 5 years (including 18 months to deal with an international procedure under the ICCPR or the

\footnotetext{
${ }^{86}$ For an overview of the role of the Privy Council: see Neuberger, 'The Judicial Committee of the Privy Council in the 21st Century' (2014) 3(1) Cambridge Journal of International and Comparative Law 30.

${ }^{87}$ Antoine, Rose-Marie B., 'Waiting to Exhale: Commonwealth Caribbean Law and Legal Systems' (2005) 29 Nova Law Review 141.

${ }^{88}$ [1994] 2 AC 1. See William A Schabas, 'Soering's Legacy: The Human Rights Committee and the Judicial Committee of the Privy Council Take a Walk down Death Row' (1994) 43(4) The International and Comparative Law Quarterly 913.

${ }^{89}$ Soering v United Kingdom [1989] 11 EHRR 439.

${ }^{90}$ Schabas, above n 88 .
} 
ACHR) would constitute an inhuman or degrading treatment, thus incompatible with the Jamaican constitution. This meant that after 5 years on death row, a death penalty had to be commuted to a life sentence. ${ }^{91}$ As a result, it was no longer possible for these states to implement the death penalty, even if both the ICCPR and the ACHR explicitly accept such limitations to the right to life, ${ }^{92}$ as death row inmates systematically applied to either the Human Rights Committee or the Inter-American Commission and benefitted from the slow working of the domestic judicial systems. ${ }^{93}$

At the time of Pratt, an overwhelming majority of the population of both countries were in favour of resuming the imposition of the death sentence. ${ }^{94}$ The exits were triggered in response to these domestic pressures. However, the moves were unsuccessful on their own terms. The most obvious limit was that Jamaica exited from the first OP-ICCPR but did not remove the right of individual applications to the InterAmerican Commission under the ACHR. Additionally, international and domestic pressure continued to be applied. Both states are members of a series of UN human rights supervisory mechanisms (UN Universal Periodic Review, special mechanisms etc.) which have persistently affirmed that the death row phenomenon is in breach of UN human rights standards. ${ }^{95}$ More importantly, despite the denunciation, the case-law of the Privy Council became even more specific, leaving fewer options for the states concerned ${ }_{2}^{96}$ by continued reference to international human rights norms.

\footnotetext{
${ }^{91}$ James Campbell, 'Murder Appeals, Delayed Executions, and the Origins of Jamaican Death Penalty Jurisprudence' (2015) 33(2) Law and History Review 435.

92 ICCPR, art 6(2); ACHR, art 4(2).

${ }^{93}$ Campbell, above n 91.

${ }^{94}$ 96\% in Trinidad and Tobago, 87\% in Jamaica. Helfer, above n 38, 1885.

${ }^{95}$ See for instance: for Jamaica, the Report of the Special Rapporteur on torture of 2010.

A/HRC/16/52/Add.3

${ }^{96}$ Thomas v Baptiste [2000] 2 AC 1. Appeal stemming from Trinidad and Tobago.
} 
As dramatic evidence of this continued domestic pressure, Jamaica made the choice of revising its bill of rights found in the constitution. ${ }^{97}$ In order to deal with the death row phenomenon, the amended bill of rights includes the death penalty as an exception to the right to life, but also states specifically in section 13(8)(a) that the duration of time spent on death row cannot be read as being an inhuman and degrading treatment. Finally, both states have tried to move away from the Privy Council and join a new final court of appeal, the Caribbean Court of Justice. But as of April 2018, the Jamaican Parliament has still been unable to pass the necessary legislation, and even then, the Caribbean Court of Justice has also started referring to the international human rights regime to help to interpret domestic norms. ${ }^{98}$ This illustrates the staunch resistance by domestic actors to the resumption of the death penalty, partly by the empowerment provided by international human rights interpretation, ${ }^{99}$ as well as the pervasive role of the function system of human rights law.

Overall, the exits from the individual application systems evidently created an end to their applicability. However, participation in the increasingly juridified regime of human rights law has not stopped, with an ongoing interaction between the international human rights regime and the domestic constitutional protections seriously impeding the possibility to legally resume the execution of the death penalty. Helfer has used these examples in light of juridification ${ }^{100}$ to contend that 'overlegalizing human rights can lead even liberal democracies to reconsider their commitment to international

\footnotetext{
${ }^{97}$ Derek O'Brien and Se-Shauna Wheatle, 'Post-Independence Constitutional Reform in the Commonwealth Caribbean and a New Charter of Fundamental Rights and Freedoms for Jamaica' [2012] (October) Public Law 683.

${ }^{98}$ Salvatore Caserta, 'The Contribution of the Caribbean Court of Justice to the Development of Human and Fundamental Rights' (2018) 18(1) Human Rights Law Review 170.

${ }_{99}$ O'Brien and Wheatle, above n 97, 692.

${ }^{100}$ Helfer, above n 38, 1836.
} 
institutions that protect those rights'. ${ }^{101}$ Such an issue, is no longer a mere intellectual debate also in Europe. Several UK Prime Ministers have seriously considered the possibility of withdrawing from the ECHR and such a withdrawal has been part of UK political debate since $2005 .{ }^{102}$ For the time being, it seems that the idea has been shelved, but it may arise again once the Brexit issue has been solved.

\subsection{Exiting the International Centre for the Settlement of Investment Disputes}

The second case concerns Bolivia, Ecuador and Venezuela's exits from the International Centre for the Settlement of Investment Disputes (ICSID). The effects of juridification by ICSID and its tribunals (the organization system) in the international investment regime (the function system) not only played a key role in prompting exits from this IO, but also appear to perpetuate established features of investor-state arbitrations in an alternative dispute settlement organization currently under negotiation.

At a meeting of the Bolivarian Alliance for the People of Our America (ALBA) in April 2007, Bolivia, Ecuador and Venezuela jointly declared their intention to withdraw from the ICSID Convention ${ }^{103}$ and terminate their membership in response to the threats of multinational enterprises resorting to ICSID arbitrations. ${ }^{104}$ Bolivia was first to denounce the Convention in May 2007, ${ }^{105}$ with Ecuador and Venezuela following suit

\footnotetext{
${ }^{101}$ Helfer, above n 38.

102 Katja S Ziegler, Elizabeth Wicks and Loveday Hodson, 'The UK and European Human Rights: A Strained Relationship?' in Katja S Ziegler, Elizabeth Wicks and Loveday Hodson (eds), The UK and European Human Rights : A Strained Relationship? (Hart Press, 2015) 3.

${ }^{103}$ Convention on the Settlement of Investment Disputes Between States and Nationals of Other States, opened for signature 3 March 1965, 575 UNTS 159 (entered into force on 14 October 1966) ('ICSID Convention').

${ }^{104}$ Mariana Durney, 'Legal Effects and Implications of the Denunciation of the ICSID Convention on Unilateral Consent Contained in Bilateral Investment Treaties: A Perspective from Latin American Cases' (2013) 17(1) Max Planck Yearbook of United Nations Law 221, 234.

105 'Bolivia Denounces ICSID Convention' (2007) 46 ILM 973.
} 
in 2009 and 2012 respectively. ${ }^{106}$ The reasons stated for withdrawing echoed certain criticisms developed in the academic literature and domestic public opinion against ICSID and the Investor-State Dispute Settlement (ISDS) system in general. ${ }^{107}$ For instance, the then Bolivian Minister of Legal Defence highlighted the following features: 'pro-business' partiality of arbitrations; closed-door proceedings; their excessive costs and the inclusion of lucrum cessans in the quantification of damages. ${ }^{108}$

Ecuador and Venezuela gave similar justifications, but also added that being members of an ISDS institution would be in conflict with their own constitutions. ${ }^{109}$ For its part, Ecuador claimed that the jurisdiction of ISDS tribunals would have clashed with its recently adopted 2008 Constitution, ${ }^{110}$ while Venezuela pointed to a provision of its 1999 Constitution limiting the validity of foreign claims on public contracts outside domestic courts. ${ }^{111}$ Regardless of the substance of these claims, the very fact

${ }^{106}$ In addition to that, the three states also terminated several (but not all) bilateral investment treaties. See UNCTAD, Investment Policy Hub, <http://investmentpolicyhub.unctad.org>. To date, Venezuela has only terminated its bilateral investment treaty with the Netherlands.

${ }^{107}$ For a compelling analysis see M Sornarajah, Resistance and Change in the International Law on Foreign Investment (Cambridge University Press, 2015).

${ }^{108}$ E Arismendi, 'La Experiencia del Estado Plurinational de Bolivia en el Centro de Arreglos de Differencias Relativas a Inversiones (CIADI)’, <http://www.ohadac.com/telechargement/bibliographie/10/0/experiencia-boliviana-en-el-ciadi-en-elcentro-de-arreglos-de-diferencias-relativas-a-inversiones.arismendi-elizabeth.pdf $>$. See also R Palanco Lazo, 'Two Worlds Apart: The Changing Features of International Investment Agreements in Latin America' in Attila Tanzi and others (eds), International Investment Law in Latin America: Problems and Prospects (Brill Nijhoff 2016) 68-97, 76.

109 Ibid.

${ }^{110}$ Constitution of the Republic of Ecuador, arts 339, 416(12) and 422,

<https://www.oas.org/juridico/pdfs/mesicic4_ecu_const.pdf>. The latter article explicitly prohibiting the adoption of international investment agreements, apart from regional ones.

${ }^{111}$ Constitution of the Bolivarian Republic of Venezuela, art 151,

<http://www.cne.gob.ve/web/normativa_electoral/constitucion/titulo4.php\#cap1sec5>. After the denunciation, Bolivia's 2009 Constitution made expressed preference to prioritising national to foreign investment and prohibiting foreign jurisdiction. See Constitution of the Plurinational State of Bolivia, Art. $320(1)$. 
that they were raised signals the discord between an international regime, which ICSID helped to juridify, and domestic democratic orders. ${ }^{112}$

Indeed, the role of ICSID in juridification goes beyond its internal structures and functions. While these consist of promoting an effective dispute settlement system for foreign investors and states according to the application of protection standards under the consent of member states, ${ }^{113}$ its operation is also deeply nested in the complex bundle of international investment treaties, national investment laws and investor-state contracts. ${ }^{114}$ In fact, ICSID’s influence in developing international investment law could not happen without the mushrooming of international investment agreements since the $1990 \mathrm{~s},{ }^{115}$ and the interpretations of substantive standards and procedural rules given by its tribunals. ${ }^{116}$

One notable example is the expanded content of the 'fair and equitable treatment' standard, the most invoked in ISDS arbitrations. This standard first appeared in international investment treaties as an indeterminate obligation of conduct on the part of the state hosting the investment, whose specific content followed a progressive expansion from its hazy formulations under customary and treaty law. ${ }^{117}$ In this regard, the role of ICSID tribunals has been crucial in producing a clearer definition of the

\footnotetext{
${ }^{112}$ For a more detailed analysis see Carlos Bellei Tagle, 'Arbitraje De Inversiones En América Latina: De La Hostilidad a La Búsqueda de Nuevas Alternativas’ in Attila Tanzi et al (eds), International Investment Law in Latin America Problems and Prospects (Brill Martinus Nijhoff, 2016) 98, 115-125.

${ }^{113}$ Convention on the settlement of investment disputes between States and nationals of other States, opened for signature 18 March 1965, 575 UNTS 159 (entered into force 14 October 1966) ('ICSID Convention').

${ }^{114}$ For a compelling analysis of how this substantive role was shaped through the leading work of ICSID's Secretary Generals and World Bank's legal counsels see Sergio Puig, 'Emergence \& Dynamism in International Organizations: ICSID, Investor-State Arbitration \& International Investment Law' (2012) 44 Georgetown Journal of International Law 531.

${ }^{115}$ But also of national laws allowing for ISDS mechanisms, including ICSID, as well as investor-state contracts containing arbitration clauses.

116 The majority of known ISDS arbitrations has taken place under ICSID. See UNCTAD, Word Investment Report (2017) <http://unctad.org/en/PublicationsLibrary/wir2017_en.pdf>, 115.

117 Sornarajah, above n 107, 247-250.
} 
standard ${ }^{118}$ and in expanding its reach to additional sub-categories, ${ }^{119}$ which restrict the conduct of the host state towards the foreign investor in ways that could hardly be foreseen at the time of the adoption of international investment treaties. For instance, following the path of other tribunals, in Occidental v. Ecuador the arbitrators found that the fair and equitable treatment standard contained an obligation of proportionality on the state towards foreign investors. ${ }^{120}$ The tribunal awarded almost USD 1.8 billion in damages to the claimant after recognizing that the expropriation of the investor's assets was a disproportionate reaction to a breach of Ecuadorian law and the contract entered into by the foreign investor, despite the fact that both Ecuadorian law and the investorstate contract allowed for such discretionary power of the Ecuadorian President. ${ }^{121}$

Yet, ICSID's contribution to the juridification of the international investment regime went beyond law-making through interpretation: ICSID itself has also provided an institutional platform for an extended and complex community of professionals involved in forms of expert rule, to the extent that Sands has recently labelled it a 'capturing' of the regime, where high legal fees are charged and 'double hatting' is practised. $^{122}$

${ }^{118}$ Interpretation relying on essentially one case under the US-Mexico Claims. See Técnicas Medioambientales Tecmed, S.A. v. The United Mexican States (Award) (2003) ICSID Case No. ARB (AF)/00/2, [154], re-interpreting L. F. H. Neer and Pauline Neer (U.S.A.) v. United Mexican States (1926) RIAA Vol IV 60. Sornarajah, above n 107.

${ }^{119}$ Rudolf Dolzer, 'Fair and Equitable Treatment: Today's Contours' (2014) 12(1) Santa Clara Journal of International Law 7.

${ }^{120}$ Occidental Petroleum Corporation and Occidental Exploration And Production Company v. The Republic of Ecuador (Award) (2012) ICSID Case No. ARB/06/11. The request for arbitration was filed in May 2006, a year before the ALBA meeting declaring the future exits.

${ }^{121}$ Ibid., [396]-[409]. The applicability of the proportionality test was based on both an interpretation of the fair and equitable treatment standard in the international investment treaty, and on Ecuadorian constitutional law.

${ }^{122}$ Philippe Sands, 'Reflections on International Judicialization' (2016) 27(4) European Journal of International Law 885, 893. The term 'double hatting' refers to the situation where arbitrators can work as party counsels, expert witnesses and tribunal secretaries in other disputes: see Malcolm Langford, Daniel Behn and Runar Hilleren Lie, 'The Revolving Door in International Investment Arbitration' (2017) 20(2) Journal of International Economic Law 301. 
Recalling the various claims made by the three exiting states above, the links between the juridification of the international investment regime, ICSID and state exits come to the fore. The latter are an attempt to escape the direct effect of international obligations contracted under the IO (the organization system) and their effect on applying and enforcing juridified standards of international investment protection in the wider function system. However, also in this case, juridification has extended the normative effects of the regime beyond issues of membership loss and treaty withdrawal. ${ }^{123}$ Indeed, under the initiative of Ecuador, the Union of South American Nations (UNASUR) has set up a high-level working group to consider the establishment of an alternative centre for settling international investment disputes. ${ }^{124}$ While the working group is currently negotiating a draft convention, which includes the establishment of a permanent tribunal, ${ }^{125}$ recent commentaries report that the proposal replicates in essence key features of ICSID, ${ }^{126}$ including the possibility of arbitration for foreign nationals from states that are not members of UNASUR. ${ }^{127}$

Overall, the current situation illustrates how the institutional mechanisms of ICSID, which the three states have pointed at to justify their exits, reappear in the proposals for an alternative initiative under UNASUR. Moreover, the jurisprudence of ICSID

\footnotetext{
${ }^{123}$ A legal consequence connected to withdrawals from ICSID is the continued jurisdiction of arbitral tribunals due to the 'sunset clauses' of the ICSID Convention (arts 71-72). See Durney, above n 104.; Antonio R Parra, 'Participation in the ICSID Convention' (2013) 28(1) ICSID Review - Foreign Investment Law Journal 169.

${ }^{124}$ Bellei Tagle, above n 112, 125.

${ }^{125}$ UNASUR, 'XIII Reunión Presencial del Grupo de Trabajo de Expertos de Alto Nivel sobre Solución de Controversias en Materia de Inversiones De UNASUR' (2016), <http://docs.unasursg.org/>.

${ }^{126}$ Javier Echaide, 'Inversiones y Solución de Controversias: El Proyecto Dentro de La Unasur y Propuestas Alternativas' (2017) 17 Anuario Mexicano de Derecho Internacional 369.

127 A similar approach to the ICSID Additional Facility Rules. See Fach Gómez, Katia and Catharine Titi, 'El Centro De Solución De Controversias En Materia De Inversiones De Unasur: Comentarios Sobre El Borrador De Acuerdo Constitutivo' (2016) 7(3) Investment Treaty News Quarterly <https://www.iisd.org/sites/default/files/publications/iisd-itn-august-2016-english.pdf>.
} 
tribunals on substantive legal standards might also influence interpretations made by arbitral tribunals set up under the proposed regional dispute settlement centre.

\subsection{Exiting the Paris Agreement on climate change}

The third and final case concerns the US declared intention to exit the 2015 Paris Agreement on climate change and its institutional regime. It highlights the normative effects of juridification from a treaty-based institutional regime ${ }^{128}$ on the exiting state, which have led to the strengthening of linkages between its sub-national entities (mostly states and cities) and the environmental goals and processes established under the Agreement's umbrella. This influence could not happen without the decisions and processes established by the Conference of the Parties (COP) of the United Nations Framework Convention on Climate Change (UNFCCC), accepted by actors other than state parties as the central regulatory framework for global action on climate change beyond inter-state relations. Under systems theory lenses, the organization system (COP) of the treaty-based regime has extended its normative reach to the wider function

128 The term regime here defines the lex specialis of the three multilateral climate change treaties and the numerous decisions and institutional processes under their respective treaty bodies, generally named Conferences of the Parties (COPs). The treaties are the United Nations Framework Convention on Climate Change, opened for signature 9 May 1992, 1771 UNTS 107 (entered into force 21 March 1994) ('UNFCCC'); Kyoto Protocol to the United Nations Framework Convention on Climate Change, opened for signature 11 December 1997, 2303 UNTS 162 (entered into force 16 February 2005); and Paris Agreement, opened for signature 12 December 2015, UN Doc. FCCC/CP/2015/L.9/Rev.1 (12 December 2015) 21 (entered into force 4 November 2016). See the approach of Cinnamon P Carlarne, Kevin R Gray and Richard Tarasofsky (eds), The Oxford Handbook of International Climate Change Law (Oxford University Press, 2016). As to the 'soft' institutional nature of COPs, which are not generally regarded IOs, see Robin R Churchill and Geir Ulfstein, 'Autonomous Institutional Arrangements in Multilateral Environmental Agreements: A Little-Noticed Phenomenon in International Law' (2000) 94(4) The American Journal of International Law 623. 
system of the transnational regime complex for climate change, which comprises the actions and informal linkages of non-state actors. ${ }^{129}$

In June 2017, the US declared its intention to exit the 2015 Paris Agreement on Climate Change with a press statement of its President. ${ }^{130}$ In the following month, it submitted a communication to the UN Secretary General, acting as Depositary of the treaty, of its intention to withdraw -an act not required under the withdrawal clause of the Agreement, ${ }^{131}$ but which has enabled the US to voice and clarify the rationale for a future exit. As made explicit both in the statement and the communication, the US Administration perceives the agreement struck in Paris as unfair, due to the allegedly disproportional financial burdens that the state will likely endure should it remain in the regime. According to the statement, the Agreement works 'to the exclusive benefit of other countries, leaving American workers (...) and taxpayers to absorb the cost in terms of lost jobs, lower wages, shuttered factories, and vastly diminished economic production. ${ }^{132}$ While such a cost/benefit narrative recalls the earlier US refusal to ratify the Kyoto Protocol in $2001,{ }^{133}$ the President's statement also highlights unspecified 'legal and constitutional issues' related to the implementation of the Agreement and recognizes in the future withdrawal 'a reassertion of America's sovereignty'. ${ }^{134}$ On its part, the communication of the US Department of State clarifies that the strategy behind

\footnotetext{
${ }^{129}$ Kenneth W. Abbott, 'The Transnational Regime Complex for Climate Change' (2012) 30(4) Environment and Planning C: Government and Policy 571.

130 The White House, Statement by President Trump on the Paris Climate Accord (1 June 2017) $<$ https://www.whitehouse.gov/briefings-statements/statement-president-trump-paris-climate-accord $>$. ${ }^{131}$ Art. 28(1,2) stipulates that withdrawal can take effect only after three years since the entry into force of the Agreement, and that the notification of withdrawal will take effect after one year from its date of receipt.

${ }^{132}$ Statement by President Trump on the Paris Climate Accord, above n 121.

${ }^{133}$ Cass R Sunstein, 'Of Montreal and Kyoto: A Tale of Two Protocols' (2007) 31 Harvard Environmental Law Review 1.

${ }^{134}$ Ibid.
} 
the threat of withdrawal is to 're-engage' in the Agreement 'if the United States can identify terms that are more favorable to it'. ${ }^{135}$ In essence, while not stopping its participation under the UNFCCC/PA treaty bodies and processes, the US appears to strategically use its non-implementation ${ }^{136}$ of the Agreement and threat of withdrawal to revise its future contribution to carbon mitigation and other commitments under the regime. ${ }^{137}$

If the dissatisfaction of the US with the Paris Agreement is explicit, the relationship between its threatened withdrawal and the juridification of the regime is perhaps subtler. In fact, the Paris Agreement should not just be seen as the outcome of the $21^{\text {st }}$ meeting of the UNFCCC COP but also as the final milestone of a lengthy and convoluted negotiation path which started in 2007 with a COP Decision in Bali. ${ }^{138}$ The following COP negotiations and technical activities of other UNFCCC subsidiary bodies have led to new regulatory processes and outcomes under the form of COP decisions and technical guidance instruments. ${ }^{139}$ These have established clear boundaries for negotiating the final outcome of the Paris Agreement, given that some of its procedural obligations were already envisioned and structured in previous COP decisions. ${ }^{140}$

\footnotetext{
${ }^{135}$ Communication Regarding Intent To Withdraw From Paris Agreement (4 August 2017) U.S. Department of State <http://www.state.gov/r/pa/prs/ps/2017/08/273050.htm>.

${ }^{136}$ In concurrence to these declarations, the Federal Government has also started a reform process of its climate change policies. See Michael Mehling, 'A New Direction for US Climate Policy: Assessing the First 100 Days of Donald Trump's Presidency’ (2017) 11(1) Carbon \& Climate Law Review 3.

137 This strategic use of the 'exit threat' is well acknowledged in the literature and in the previous practice of the US. See, for instance, Magliveras, above n 6, 100-101.

138 Bali Action Plan, Decision 1/CP.13, UN Doc. FCCC/CP/2007/6/Add.1.

${ }^{139}$ Daniel Bodansky, Jutta Brunnée and Lavanya Rajamani, International Climate Change Law (Oxford University Press, 2017) 97-117.

140 To give but two examples, the 2011 Durban Platform for Enhanced Action clarified that the outcome of negotiations should have taken the form of a 'legal instrument or agreed legal outcome with legal force.'; and the 2013 COP in Warsaw set up via a decision the process of 'intended nationally determined contributions' in reducing emissions, which the Paris Agreement makes obligatory through the submission of Nationally Determined Contributions. See, respectively, Establishment of an Ad Hoc Working Group on the Durban Platform for Enhanced Action, Decision 1/CP.17, UN Doc.
} 
However, the normative effects of juridification under the UNFCCC institutional regime have also manifested in the form of reaction and resistance to a potential US withdrawal from some of its sub-national entities. For instance, in the aftermath of the federal government decision, several US states have created the United States Climate Alliance, an initiative 'committed to reducing greenhouse gas emissions consistent with the goals of the Paris Agreement'. ${ }^{141}$ According to its principles, states participating are to 'implement policies that advance the goals of the Paris Agreement, aiming to reduce greenhouse gas emissions by at least $26-28$ percent below 2005 levels by $2025^{\prime} \cdot{ }^{142}$ In addition to states, the Climate Mayors initiative has gathered 402 US cities, representing almost 70 million US citizens. This association declared that it will 'adopt, honor, and uphold the commitments to the goals enshrined in the Paris Agreement'. ${ }^{143}$ The linkage between US sub-national entities and the international climate change regime has also taken an institutional form, since the launch by the UNFCCC Secretariat of the Nonstate Actor Zone for Climate Action, which registers and publishes climate-related commitment and initiatives by a wide range of non-state actors. ${ }^{144}$ All of these actions show how the norms stemming from the COP have gone beyond the formal state participation to an organization regime to extend to a function regime.

FCCC/CP/2011/9/Add.1, [2]; and Further advancing the Durban Platform, Decision 1/CP.19, UN Doc. FCCC/CP/2013/10/Add.1, [1(b)].

${ }^{141}$ United States Climate Alliance, <https://www.usclimatealliance.org/alliance-principles〉 (italics added).

142 This target corresponds to the one submitted by the previous US Administration under the Paris Agreement. See (untitled)

<http://www4.unfccc.int/ndcregistry/PublishedDocuments/United\%20States\%20of\%20America\%20First/ U.S.A.\%20First\%20NDC\%20Submission.pdf>

${ }^{143}$ See Climate Mayors, 406 US Climate Mayors commit to adopt, honor and uphold Paris Climate Agreement goals, <http://climatemayors.org/actions/paris-climate-agreement $>$.

${ }^{144}$ See UNFCCC, NAZCA Tracking Climate Action, <http://climateaction.unfccc.int/〉. Harro van Asselt, 'The Role of Non-State Actors in Reviewing Ambition, Implementation, and Compliance under the Paris Agreement' (2016) 6(1-2) Climate Law 91. 
Despite the US intent to exit the Paris Agreement and the organization system of its treaty body, ${ }^{145}$ the principles, targets and processes enshrined therein might still be effective throughout parts of the US territory via their parallel acceptance by non-state actor initiatives and institutional linkages with the wider transnational function regime.

\section{A new variable in the 'exit' equation?}

By looking at the juridification of IOs and its repercussions on international and domestic legal regimes, the perspective shifts from debates on the legality of exit and the consequences between the exiting state and the IO to the normative effects of the IO on the juridified function system. Under this wider perspective, a regulatory dilemma suddenly becomes more vivid. In the three illustrative cases, juridified IOs, acting according to the legal codes of their constitutive instruments, have failed to take into account strongly held domestic visions, thus contributing to decisions on exits.

Moreover, exiting states have been left with no guarantee of avoiding some normative effects from juridification on the function system and, as a result, this has limited the effects of exiting (or threatening to exit) the IO. ${ }^{146}$ These outcomes relate to two key aspects of systems theory: the operational closure of juridified legal systems and the IO's influence on legal sub-regimes, which are function systems.

Also, the same cases evidence two legal techniques of juridification: third-party interpretation on the one hand, and the extended reach of norms and processes through

\footnotetext{
${ }^{145}$ It is formally named 'The Conference of the Parties serving as the meeting of the Parties to the Paris Agreement': see Paris Agreement, art 16.

${ }^{146}$ Certainly, there will always be important consequences from an exit. For instance, in the case of US withdrawal from the Paris Agreement, the compliance and transparency processes of the latter will not apply to sub-national entities and these will not be subject to international monitoring and accountability for not complying with standards and processes under the Agreement.
} 
the work of non-state actors on the other. As to the first, the examples of the interpretation of the prohibition of inhuman treatment in human rights law and the fair and equal treatment standard in international investment law highlight the role of independent expert-rule in deciding vaguely formulated standards with a teleological approach. ${ }^{147}$ In the absence of judicialization, norm interpretation is normally left to each member state, according to the argumentative techniques under the vocabulary of general international law. This enables states to voice political views with their own interpretations, ${ }^{148}$ with the result that, in a lightly juridified IO, general international law enables informal 'coupling' with domestic politics; something that does not happen with an IO working as an organization system. Being an autopoietic system means that the interpretation provided by autonomous bodies does not need to take into account domestic justifications. This is a choice purely dependent on the construction of what is a valid legal argument in the function system, as two of the examples covered show. The Human Rights Committee and the Inter-American Commission have indirectly ${ }^{149}$ banned the death penalty contrary to the letter of the international human rights treaties and to what was originally consented to. In so doing, the domestic views on criminal policies were considered but not as an element of the legal reasoning. ${ }^{150}$ Likewise, in the international investment regime, the combined effect of international investment treaties and the ICSID Convention makes it difficult for states to pursue domestic policy

\footnotetext{
${ }^{147}$ For human rights see George Letsas, 'The ECHR as a Living Instrument: Its Meaning and Legitimacy' in Andreas Føllesdal, Birgit Peters and Geir Ulfstein (eds), Constituting Europe: The European Court of Human Rights in a National, European and Global Context (Cambridge University Press, 2013) 106. For international investment law see Sornarajah, above n 107, 246-299.

${ }^{148}$ Martti Koskenniemi, From Apology to Utopia: The Structure of International Legal Argument (Cambridge University Press, 2006) 333.

${ }^{149}$ Helfer, above n 38, 1874.

${ }^{150}$ Pratt v. Jamaica, Communication Nos. 210/1986 \& 225/1987, U.N. GAOR, Hum. Rts. Comm., 44th Sess., Supp. No. 40, at 222, U.N. Doc. A/44/40 (1989).
} 
alternatives to the political economy promoted by prevalent interpretations of international standards. ${ }^{151}$

On the second technique, we noticed how in systems theory IOs are not only social systems, but they also participate in wider function systems comprising multiple actors, including domestic actors. This points at another limit of understanding exits only through the functionalist lens of international institutional law and applicable international obligations. Under the proposed framework, non-state actors voluntarily participate in the function system, as enablers of specific normative effects and in recognition of the centrality of the organization system. In the case of the Caribbean states, the Privy Council was the major domestic vector of the integration of legal solutions created within international human rights law. ${ }^{152}$ The British judges reached this solution by assuming that the norms laid out in the domestic Bill of Rights should be interpreted in light of the international equivalent, ${ }^{153}$ so that the domestic legal order would absorb but also influence the international regime. This was not a necessary conclusion. It was possible, for instance, for the Privy Council to decide that the specific constitutional norm had first to be interpreted within the context of domestic institutions. ${ }^{154}$ Regarding the Paris Agreement, sub-national actors, such as cities or US state governments, voluntarily intervened and joined the process-based regime of COP

\footnotetext{
${ }^{151}$ Jonathan Bonnitcha, Lauge N Skovgaard Poulsen and Michael Waibel, The Political Economy of the Investment Treaty Regime (Oxford University Press, 2017) 93-125.

${ }^{152}$ Schabas, above n 88.

${ }^{153}$ Pratt v. Attorney-General for Jamaica [1994] 2 AC 1.

${ }^{154}$ This was for instance the approach taken by the British Supreme Court in R. v Horncastle (Michael Christopher) [2009] UKSC 14. In that case, the Court refused to follow the established case-law of the European Court of Human Rights to choose an interpretation more in line with the common law understanding of the issue. Interestingly, this led to a change of approach of the Strasbourg Court. See Nicolas Bratza, 'The Relationship between the UK Courts and Strasbourg' (2011) 5 European Human Rights Law Review 505.
} 
meetings outside the structures of membership, but still making key IO norms and processes effective in the wider transnational regime complex for climate change.

All the elements and techniques discussed here show that, if member states wish to exit from IOs in reaction to their juridification, this might not lead to a full escape, as it would be expected under more formalistic assumptions.

\section{Conclusions}

With a view to complement the perspective offered by functionalism and formalistic approaches to unilateral exits from IOs, this paper has focused on juridification as a phenomenon of legal growth within IOs and a possible cause of state exits. We have used systems theory as a sociological tool to better understand the impact of formalization through juridification, coupled with informal techniques of law-making. While this approach cannot say anything about the legal validity of the effects created by IO acts on the wider function regimes, it offers a solid framework to understand these effects from a legal systems perspective.

Accordingly, by looking at cases of highly juridified IOs we found that, while exits are indeed about withdrawing from a multilateral treaty with the ensuing cessation of membership, as well as rights and obligations, states wishing to exit might only partially achieve the desired aims of full disentanglement from the IO's internal law; instead, they will still be somehow affected under the wider regime where the IO operates.

Awareness of juridification via bolstered expert rule, bureaucratization, and participation of non-state actors, can lead to more complete judgements on the tensions between domestic and supranational systems. So, those advocating for centrifugal pulls 
from IO-centred orders should further assess to what extent full detachment can be achieved and what other measures, other than formal exits, would be needed for achieving the exit goal. By the same token, a more complete framing of the legal techniques for juridification can help those contributing to it to better tame these tensions. However, the question remains as to whether this managerial approach would nonetheless result in even more bureaucratization and expert rule, confirming the view of juridification as an endless spiral, growing out of a legal mindset that all international lawyers somehow share. 